The Canadian Mineralogist

Vol. 43, pp. 1565-1580 (2005)

\title{
NATURAL RADIATION-INDUCED DAMAGE IN QUARTZ. I. CORRELATIONS BETWEEN CATHODOLUMINENCE COLORS AND PARAMAGNETIC DEFECTS
}

\author{
SANDA BOTIS, SERgiY M. NOKHRIN, YuANMing PAN ${ }^{\S}$, Yingkai XU ANd Thomas BONLI \\ Department of Geological Sciences, University of Saskatchewan, Saskatoon, Saskatchewan S7N 5E2, Canada
}

VLAD SOPUCK

Cameco Corporation, $212111^{\text {th }}$ Street West, Saskatoon, Saskatchewan S7M 1J3, Canada

\begin{abstract}
Quartz grains from the McArthur River uranium deposit of the Athabasca Basin, Saskatchewan, are characterized by three distinct types of cathodoluminescence (CL): 1) halos surrounding U- and Th-bearing mineral inclusions, and 2) patches and 3) continuous rims along grain boundaries and fractures. These three types of CL have a constant width of $\sim 35$ to $45 \mu \mathrm{m}$, consistent with the maximum depth of penetration of alpha particles, and therefore they record alpha-particle-induced radiation damage. Relative to the host grains, the radiation-damaged areas are characterized by pronounced but broad CL bands in the ultraviolet $(\sim 350 \mathrm{~nm})$ and red $(\sim 620-650 \mathrm{~nm})$ regions. Isochronal annealing experiments reveal that the ultraviolet CL persists to $500^{\circ} \mathrm{C}$ but is annealed out at $600^{\circ} \mathrm{C}$, whereas the red CL persists to at least $800^{\circ} \mathrm{C}$. Electron paramagnetic resonance (EPR) spectroscopy, including detailed measurements on saturation behavior and thermal properties, revealed six paramagnetic defects: one oxygen vacancy center $\left(\mathrm{E}_{1}{ }^{\prime}\right)$, three silicon vacancy hole centers $\left[\mathrm{O}_{2}{ }^{3-} / \mathrm{H}^{+}(\mathrm{I}), \mathrm{O}_{2}{ }^{3-} / \mathrm{H}^{+}(\mathrm{II})\right.$ and $\left.\mathrm{O}_{2}{ }^{3-} / M^{+}\right]$and two $\mathrm{O}_{2}{ }^{-}$peroxy centers. Spectral simulations confirm the presence of these centers. Moreover, EPR spectra of HF-treated samples show that the silicon vacancy-hole centers and the peroxy centers are concentrated in the radiation-damaged rims and fractures. Center $\mathrm{E}_{1}$ ' appears to occur throughout the quartz grains and is annealed out at $\sim 500^{\circ} \mathrm{C}$; it thus cannot be responsible for the ultraviolet or red CL. The silicon vacancy-hole centers are all annealed out between $550^{\circ}$ and $600^{\circ} \mathrm{C}$, similar to the annealing temperature of the ultraviolet $\mathrm{CL}$. The peroxy centers are the only paramagnetic defects stable above $600^{\circ} \mathrm{C}$, corresponding to the preservation of red CL in radiation-damaged areas at high temperatures. Therefore, the silicon vacancy-hole centers and the peroxy centers are probably responsible for the characteristic ultraviolet and red CL, respectively, associated with radiation-damaged halos, patches and rims in quartz.
\end{abstract}

Keywords: quartz, radiation damage, cathodoluminescence, paramagnetic defects, McArthur River uranium deposit, Athabasca Basin, Saskatchewan.

\section{SOMMAIRE}

Les grains de quartz du gisement d'uranium de McArthur River, bassin d'Athabasca, au Saskatchewan, possèdent trois types de cathodoluminescence (CL): 1) auréoles autour d'inclusions de minéraux porteurs d'uranium ou de thorium, 2) taches et 3) bordures continues le long de grains et de fractures. Les trois types de CL sont développées sur une largeur constante d'environ $\sim 35$ à $45 \mu \mathrm{m}$, ce qui concorde avec la profondeur de pénétration maximale des particules alpha, et ils témoignent donc de l'étendue du dommage dû aux particules alpha. Par rapport aux grains hôtes, les franges endommagées possèdent des bandes CL prononcées mais floues dans les régions ultraviolette $(\sim 350 \mathrm{~nm})$ et rouge $(\sim 620-650 \mathrm{~nm})$. Des expériences de recuit isochronales révèlent que le bande $\mathrm{CL}$ ultraviolette persiste jusqu'à $500^{\circ} \mathrm{C}$, mais elle disparait à $600^{\circ} \mathrm{C}$, tandis que la bande $\mathrm{CL}$ rouge persiste jusqu'à au moins $800^{\circ} \mathrm{C}$. Les spectres de résonance paramagnétique des électrons (EPR), y inclus les mesures détaillées du comportement de la saturation et des propriétés thermiques, révèlent six défauts paramagnétiques: une lacune sur un site de l'oxygène $\left(\mathrm{E}_{1}{ }^{\prime}\right)$, trois trous représentant des sites $\mathrm{Si}$ vacants $\left[\mathrm{O}_{2}{ }^{3-} / \mathrm{H}^{+}(\mathrm{I}), \mathrm{O}_{2}{ }^{3-} / \mathrm{H}^{+}(\mathrm{II})\right.$ et $\left.\mathrm{O}_{2}{ }^{3-} / M^{+}\right]$, et deux sites dus aux groupes peroxy, $\mathrm{O}_{2}{ }^{-}$. Les simulations de nos spectres confirment la présence de ces centres. De plus, les spectres EPR d'échantillons traités avec HF montrent que les centres associés aux lacunes au site Si et ceux attribués aux groupes peroxy seraient concentrés dans les bordures et le long de fractures dans le quartz endommagé. Le centre $\mathrm{E}_{1}$ ' semble caractériser le quartz de façon généralisée, et disparait à environ $\sim 500^{\circ} \mathrm{C}$; il ne pourrait donc rendre compte de la cathodoluminescence ultraviolette ou rouge. Les centres lacunaires au site Si disparaissent suite au recuit entre $550^{\circ}$ et $600^{\circ} \mathrm{C}$, dans le même intervalle que la température de recuit de la cathodoluminescence ultraviolette. Les sites à groupes peroxy seraient les seuls défauts paramagnétiques stables au delà de $600^{\circ} \mathrm{C}$, correspondant ainsi à la préservation de la cathodoluminescence rouge dans les régions endommagées à températures

$\S \quad$ E-mail address: yuanming.pan@usask.ca 
élevées. Il semble donc que les centres lacunaires au sites Si et les centres à groupes peroxy seraient responsables de la cathodoluminescence caractéristique ultraviolette et rouge, respectivement, associée aux auréoles, taches, et liserés endommagés dans le quartz.

(Traduit par la Rédaction)

Mots-clés: quartz, dommage dû à la radiation, cathodoluminescence, défauts paramagnétiques, gisement d'uranium de McArthur River, bassin d'Athabasca, Saskatchewan.

\section{INTRODUCTION}

Cathodoluminescence (CL) colors in quartz have long been applied to petrological and geochemical studies of sedimentary rocks and mineral deposits (e.g., growth zonation, twinning, fractures, provenance and dating of mineral grains; Smith \& Stenstrom 1965, Ramseyer et al. 1988, Owen 1988, Meunier et al. 1990, Bruhn et al. 1996, Penniston-Dorland 2001). Despite extensive study of this subject, the causes of CL colors in quartz are still not understood with any certainty (Götze et al. 2001, and references therein). Proposed causes include: 1) presence of trace elements (e.g., Sprunt 1981, Demars et al. 1996, Plötze \& Wolf 1996, Götze et al. 1999, 2005), 2) lattice ordering (Zinkernagel 1978), 3) occurrence of defect centers (Mitchell \& Denure 1973, Steven Kalceff \& Phillips 1995, Götze et al. 1999), 4) intrinsic properties of the $\mathrm{SiO}_{4}$ tetrahedron (Hanusiak \& White 1975); and 5) radiation damage (Siegel \& Marrone 1981, Owen 1988, Meunier et al. 1990, Götze et al. 2001).

Several authors have described radiation-damageinduced CL colors in halos or rims surrounding U- and Th-bearing mineral inclusions in quartz (Smith \& Stenstrom 1965, Morton 1978, Zinkernagel 1978, Owen 1988, Ramseyer et al. 1988, Meunier et al. 1990, G ze et al. 2001). The three major radionuclides, ${ }^{238} \mathrm{U},{ }^{235} \mathrm{U}$ and ${ }^{232} \mathrm{Th}$, each involve an alpha-decay event causing emission of a ${ }^{4} \mathrm{He}$ core of distinct energies. The colored halos have been linked to alpha particles (Owen 1988, Meunier et al. 1990, Nasdala et al. 2001). For example, Owen (1988) showed that the diameter of the concentric CL rings in halos surrounding $\mathrm{U}$ - and Th-bearing minerals match closely the distribution of the most energetic particles emitted by the decay of ${ }^{238} \mathrm{U},{ }^{235} \mathrm{U}$ and ${ }^{232} \mathrm{Th}$ (cf. Bragg \& Kleeman 1905).

More recently, Komuro et al. (2002) performed a high-energy $\mathrm{He}^{+}(4 \mathrm{MeV})$ implantation experiment on crystals of synthetic $\alpha$-quartz, using a $3 \mathrm{M}$-tandem ion accelerator in the Takasaki Research Center, Japan Atomic Energy Research Institute. Their experiment demonstrated that the alpha-particle-irradiated quartz crystals developed the characteristic CL rims with width consistent with that predicted by Owen (1988). Moreover, Komuro et al. (2002) noted that the intensity of $C L$ in the artificially irradiated quartz increases syste- matically with the radiation dosage. Therefore, there is compelling evidence, both theoretical (Owen 1988) and experimental (Komuro et al. 2002), that CL colors in halos (and rims) surrounding $\mathrm{U}$ - and Th-bearing mineral inclusions in quartz are induced by alpha-particle bombardment. However, questions remain about the nature of alpha-particle-induced radiation damage in quartz and the origin of the characteristic CL in the radiation-damaged halos (and rims) in this mineral.

The Mesoproterozoic Athabasca basin of northern Saskatchewan is home to several world-class uranium deposits (including the high-grade McArthur River deposit), which collectively represent approximately $30 \%$ of the global reserve of this strategic metal (Ramaekers 1981, Zhang et al. 2001). As part of a broad study of cathodoluminescence (CL) in quartz from the Athabasca Basin, we noted that some samples of sandstone from the McArthur River deposit are characterized by well-developed radiation-damage-induced CL, which occurs not only as halos surrounding included $\mathrm{U}$ - and Th-bearing minerals (e.g., uraninite, zircon and fluorapatite), but also as patches or a continuous rim along the grain boundaries and fractures (see also Meunier et al. 1990; Götze et al. 2001). These samples present an excellent opportunity to investigate the nature of radiation damage in quartz and the mechanism of radiation-damage-induced $\mathrm{CL}$ in this mineral.

Specifically, we report on a detailed electron paramagnetic resonance (EPR) spectroscopic study on radiation-damage-induced paramagnetic centers in a representative sample from the McArthur River deposit. Quartz separates from this sample have been subjected to systematic isochronal annealing experiments and HF treatments, and then we investigated them by detailed CL (both imaging and spectroscopy) and EPR measurements. In particular, EPR experiments were made at various temperatures (from room temperature down to $\sim 150 \mathrm{~K}$ ) and microwave powers in order to characterize the radiation-damage-induced paramagnetic defects on the basis of their saturation behaviors and thermal properties. Moreover, a comparison of the CL spectra and the thermal behaviors of the observed paramagnetic centers, together with compositional data from inductively coupled plasma - mass spectrometry (ICP-MS), permits correlations of the radiation-damaged-induced CL with specific paramagnetic centers. 


\section{SAMPLE PREPARATION and Analytical Methods}

\section{Sample preparation}

Sandstone H737-58 from the McArthur River deposit, which exhibits the most pervasively developed CL (see below), was selected for detailed investigation. Polished thin sections of this sample were first prepared for petrographic examination. A part of this sample was then soaked in distilled water for several days, crushed gently into small pieces and washed in an ultrasonic bath. The quartz grains from the ultrasonic treatment were sieved ( $>25 \mathrm{mesh}$ or $0.7 \mathrm{~mm}$ in diameter), washed and dried for several hours in air at room temperature. Pure quartz grains without any visible mineral inclusions were then hand-picked under a binocular microscope.

Isochronal annealing experiments were made on both small fragments of the original sample H737-58 and a portion of the quartz separates $(\sim 100 \mathrm{mg})$, under atmospheric pressure in a Thermolyne muffle furnace. Small fragments were held for 24 hours at the following temperatures: 100, 200, 300, 400, 450, 500, 550, 600, $700,800,900$ and $1000^{\circ} \mathrm{C}$. These fragments were then mounted in epoxy and polished for CL examinations. The quartz separates were heated sequentially from 100 to $200,300,400,450,500,550,600,700$ to $800^{\circ} \mathrm{C}$ for 24 hours each, and were extracted for EPR measurements after each interval.

Another portion of the quartz separates $(\sim 100 \mathrm{mg})$ was subjected to sequential HF treatments by immersion in concentrated HF in a teflon capsule. The quartz separates, after a total of 2, 4 and 8 hours of HF treatment, were washed in water in an ultrasonic bath, air dried and then weighed. The sample remaining after the three steps of HF treatments weighed $\sim 80, \sim 60$ and $\sim 50 \mathrm{mg}$, respectively.

\section{Cathodoluminescence $(C L)$ experiments}

Cathodoluminescence (CL) was measured and backscattered-electron (BSE) imaging of sample H737-58 were made, before and after isochronal annealing experiments, on a JEOL 8600 Superprobe electron microprobe equipped with an infrared CL detector, an energy-dispersion spectrometer and three wavelengthdispersion spectrometers at the Department of Geological Sciences, University of Saskatchewan. Both CL and BSE images were acquired using a Gellar Micro Analytical dPict digital image-acquisition system. The BSE images were acquired at an accelerating voltage of $15 \mathrm{kV}$ and a beam current of $10 \mathrm{nA}$. All CL images were obtained at $15 \mathrm{kV}$ and $75 \mathrm{nA}$.

Quantitative CL spectra were collected on a JEOL JSM-6360 scanning electron microscope equipped with a Gatan MonoCL3 spectrometer, at the University of Regina. This instrument was operated at an acceleration voltage of $5 \mathrm{kV}$, a beam current of $10 \mathrm{nA}$ and a spot beam of $\sim 1 \mu \mathrm{m}$ in diameter. The CL spectra were collected over the ranges $300-600 \mathrm{~nm}$ or $400-700 \mathrm{~nm}$, with a spectral resolution of $2 \mathrm{~nm}$.

\section{Electron paramagnetic resonance $(E P R)$ experiments}

Powder EPR spectra of quartz separates from sample H737-58 were recorded with a Bruker ESP 300E spectrometer, operating at X-band frequencies (9.5-9.7 $\mathrm{GHz}$ ), at the Department of Chemistry, University of Saskatchewan. The microwave power was varied for different experiments, but all other experimental parameters were kept constant during measurements in order to facilitate direct comparison among spectra. In particular, all EPR spectra were collected with similar amounts of powder in the same quartz tube. The microwave powers used in this study varied from $30 \mathrm{~dB}(200$ $\mu \mathrm{W})$ to $3 \mathrm{~dB}(100 \mathrm{~mW})$.

Quartz separates of H737-58 sampled after each step of isochronal annealing also have been investigated by detailed X-band EPR experiments at room temperature and seven different microwave powers $(1,3,5$, $10,15,20$ and $30 \mathrm{~dB}$ ). The EPR spectra of the quartz separates after the isochronal annealing experiments are hereafter designated by their respective temperatures (e.g., the $100^{\circ} \mathrm{C} \mathrm{EPR} \mathrm{spectra)} \mathrm{in} \mathrm{order} \mathrm{to} \mathrm{distinguish}$ them from those obtained from untreated samples (i.e., the UT spectra). It should be emphasized that all EPR spectra of quartz separates after isochronal annealing experiments were recorded at room temperature. In addition, untreated quartz separates were investigated before annealing by X-band EPR at $\sim 200 \mathrm{~K}$ and $\sim 150$ $\mathrm{K}$, by using a liquid-nitrogen flow cryostat.

$\mathrm{X}$-band EPR spectra of the HF-treated quartz separates were collected at room temperature for the following microwave powers: $10 \mathrm{~dB}(20 \mathrm{~mW}), 5 \mathrm{~dB}$ $(63.3 \mathrm{~mW})$ and $3 \mathrm{~dB}(100 \mathrm{~mW})$. Simulations of EPR spectra were made by use of the software package EPR-NMR (Mombouquette et al. 1996).

Inductively coupled plasma - mass spectrometry $(I C P-M S)$ analysis

Approximately $100 \mathrm{mg}$ of pure quartz separates were analyzed for trace elements on a Perkin-Elmer Sciex Elan 5000 ICPMS, at the Department of Geological Sciences, University of Saskatchewan. The quartz grains were digested in $\mathrm{HF}-\mathrm{HNO}_{3}$. A comparison of analytical results and recommended values of trace elements in international reference materials shows that agreements for all trace elements are within $15 \%$. 


\section{RESULTS}

\section{CL microscopy}

Sample H737-58 consists of predominantly anhedral detrital quartz grains mantled by a well-developed secondary overgrowth. The detrital quartz grains are characterized by complex but relatively weak CL of unknown origin. The secondary overgrowth, where it is not affected by U- and Th-bearing mineral inclusions or U-bearing minerals in the matrix, is generally CL-inactive (Fig. 1a). Bright CL occurs extensively as patches and, more commonly as a continuous rim along the boundaries and fractures of the detrital grains (Fig. 1a), in addition to a halo surrounding $\mathrm{U}$ - bearing mineral inclusions (Fig. 1b).

The U-bearing mineral inclusions with a well-developed CL halo in quartz grains of H737-58 include zircon, uraninite, crandallite-goyazite, fluorapatite and rutile. Monazite-(Ce) and xenotime-(Y) with a welldeveloped CL halo have been observed as inclusions in other Athabasca samples, but are not present in H73758. It is noteworthy that the CL patches occur along the margin of both detrital grains and the secondary overgrowth, whereas the continuous rim is invariably restricted to the detrital grains and is mantled by the secondary quartz overgrowth (Fig. 1c). Also, a CL halo associated with accessory minerals is generally rare or absent in the secondary overgrowth.

The CL patches and continuous rims along the boundaries and fractures are locally in direct association with U-bearing minerals (e.g., uraninite and goyazite). More commonly, however, the CL rims occur without any visible association of $U$ - or Th-bearing minerals. Nonetheless, all CL patches and rims have a constant width of $\sim 35$ to $45 \mu \mathrm{m}$ (Fig. 1a), which is identical to that of the CL halos (Fig. 1b) and is consistent with the predicted maximum depth of penetration of alpha particles from the ${ }^{238} \mathrm{U}$ and ${ }^{232} \mathrm{Th}$ decay series (Owen 1988). Therefore, the CL patches and rims (and CL halos) in H737-58 are all related to radiation damage induced by alpha particle bombardment ( $c f$. Owen 1988, Meunier et al. 1990, Komura et al. 2002).

CL images of H737-58 after annealing reveal that the radiation-damaged halos and rims remain CL-active up to at least $800^{\circ} \mathrm{C}$ (Fig. 1e), as found by Baker \& Owen (1983), who also noted that CL halos in quartz do not fade noticeably at temperatures below $800^{\circ} \mathrm{C}$. However, the CL halos and rims are annealed out at $900^{\circ} \mathrm{C}$ (Fig. 1f) and above.

\section{CL spectroscopy}

Figure 2a shows that the CL spectra of detrital quartz grains in H737-58 are characterized by broad bands in the blue $(\sim 420 \mathrm{~nm})$ and red $(\sim 620-650 \mathrm{~nm})$ regions, whereas the CL spectra of the secondary overgrowth have a low signal-to-noise ratio (Fig. 2b). The CL spectra of the radiation-damaged halos and rims are similar; both are characterized by the presence of a pronounced but broad band in the ultraviolet region ( $\sim 350 \mathrm{~nm}$; Fig. 2c), in addition to the blue and red bands. Also, a comparison of the CL spectra between the radiation-damaged halos and rims and their host grains reveals that the red-to-blue band ratio of the former is invariably greater than that of the latter. This result is consistent with the observation of Götze et al. (2001), who reported a red CL for radiation-damaged halos in quartz grains from the Witwatersrand basin, South Africa. However, the characteristic ultraviolet CL of the McArthur River sample was not detected by Götze et al. (2001). This discrepancy may be attributable to the different experimental conditions in the collection of CL spectra (i.e., $14 \mathrm{kV}$ and $10 \mu \mathrm{A}$ in Götze et al. 2001).

There is no systematic change in the CL spectra of the detrital quartz grains after annealing up to $600^{\circ} \mathrm{C}$ (Figs. 2a, d). Also, the CL spectra of the radiationdamaged halos are similar from room temperature to $500^{\circ} \mathrm{C}$ (Figs. 2c, e). However, the CL spectra of the radiation-damaged halos at $600^{\circ} \mathrm{C}$ are distinguished by the disappearance of the characteristic ultraviolet band (Fig. 2f). Also, the red-to-blue band ratio in the $600^{\circ} \mathrm{C}$ spectrum of the radiation-damaged halos (Fig. 2f) is significantly greater than that of the undamaged detrital hosts (Fig. 2d), again pointing to a red CL characteristic of the radiation-damaged halos ( $c f$. Götze et al. 2001).

\section{The EPR spectra of UT samples}

The EPR spectrum of untreated $\mathrm{H} 737-58$ at 30 $\mathrm{dB}$ (Fig. 3) is characterized by the presence of the well-known oxygen-vacancy center $\mathrm{E}_{1}$ ' (Weeks 1956, Feigl \& Anderson 1970, Jani et al. 1983, Weil 1984). This center is easily recognized by its almost uniaxial values of $g$ (2.00178, 2.0005 and 2.00033) and by its saturation behavior (see below). The structural model of $\mathrm{E}_{1}$ ' involves a vacancy left by a missing bridging $\mathrm{O}^{-}$ion between two $\mathrm{Si}$ atoms and the unpaired electron in a dangling tetrahedral $\mathrm{sp}^{3}$ orbital of a single $\mathrm{Si}$ atom bonded to three O atoms (Yip \& Fowler 1975).

The EPR spectra of untreated H737-58 at higher microwave powers revealed the presence of additional paramagnetic centers, which are indicated by a multitude of lines in the $\mathrm{g}$ region from $\sim 2.001$ to $\sim 2.049$ (Fig. 3). However, these EPR lines on the spectra of the UT samples are difficult to interpret owing to their similarities in saturation behavior. In particular, several EPR lines with effective g values around 2.002-2.007 have very similar dependence on microwave power. 

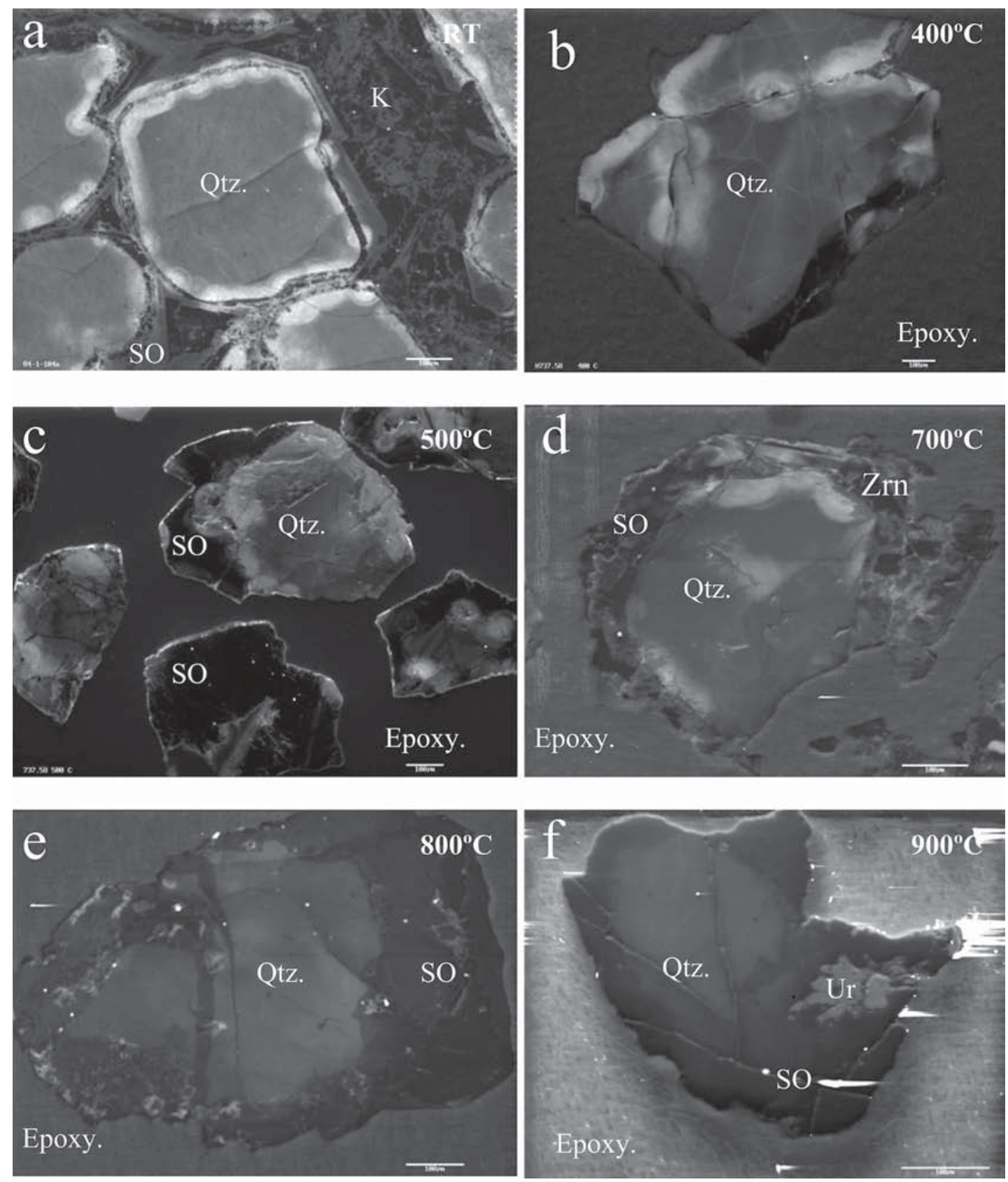

FIG. 1. Cathodoluminescence (CL) images of H737-58 illustrating: a) bright radiation-damage induced CL as patches and rims along the boundaries and fractures of detrial quartz grains (Qtz) and their secondary overgrowth (SO). Also present are clay minerals (mainly kaolinite, $\mathrm{K}$ ) in matrices; b) bright CL rims along the boundaries and fractures of detrital quartz grains after isochronal annealing at $400^{\circ} \mathrm{C}$; c) well-preserved CL patches, rims and halos in detrital quartz grains mantled by CL inactive secondary overgrowth (SO) after annealing at $600^{\circ} \mathrm{C}$; d) well-preserved CL halo surrounding a zircon (Zrn) inclusion in a detrital quartz and CL patches along the grain boundaries of detrital quartz after annealing at $700^{\circ} \mathrm{C}$; e) weak but visible $\mathrm{CL}$ rims and halos in detrital quartz after annealing at $800^{\circ} \mathrm{C}$; and f) no visible CL rims on detrital quartz grains after annealing at $900^{\circ} \mathrm{C}$. Note that no CL halos occur around the uraninite (Ur) inclusion in the secondary overgrowth. 
The EPR spectra after isochronal annealing experiments

The 100 and $200^{\circ} \mathrm{C}$ EPR spectra are similar in the number of peaks to those of their UT counterparts at the same microwave powers (Fig. 4). However, the overall intensities of the 100 and $200^{\circ} \mathrm{C}$ spectra increase significantly relative to those of the UT spectra (Fig. 4). Also, the overall intensity of the $200^{\circ} \mathrm{C}$ spectrum is notably higher than that of the respective $100^{\circ} \mathrm{C}$ counterpart. The 300,400 and $450^{\circ} \mathrm{C}$ spectra also are similar in the number of peaks to those of the UT , 100 and

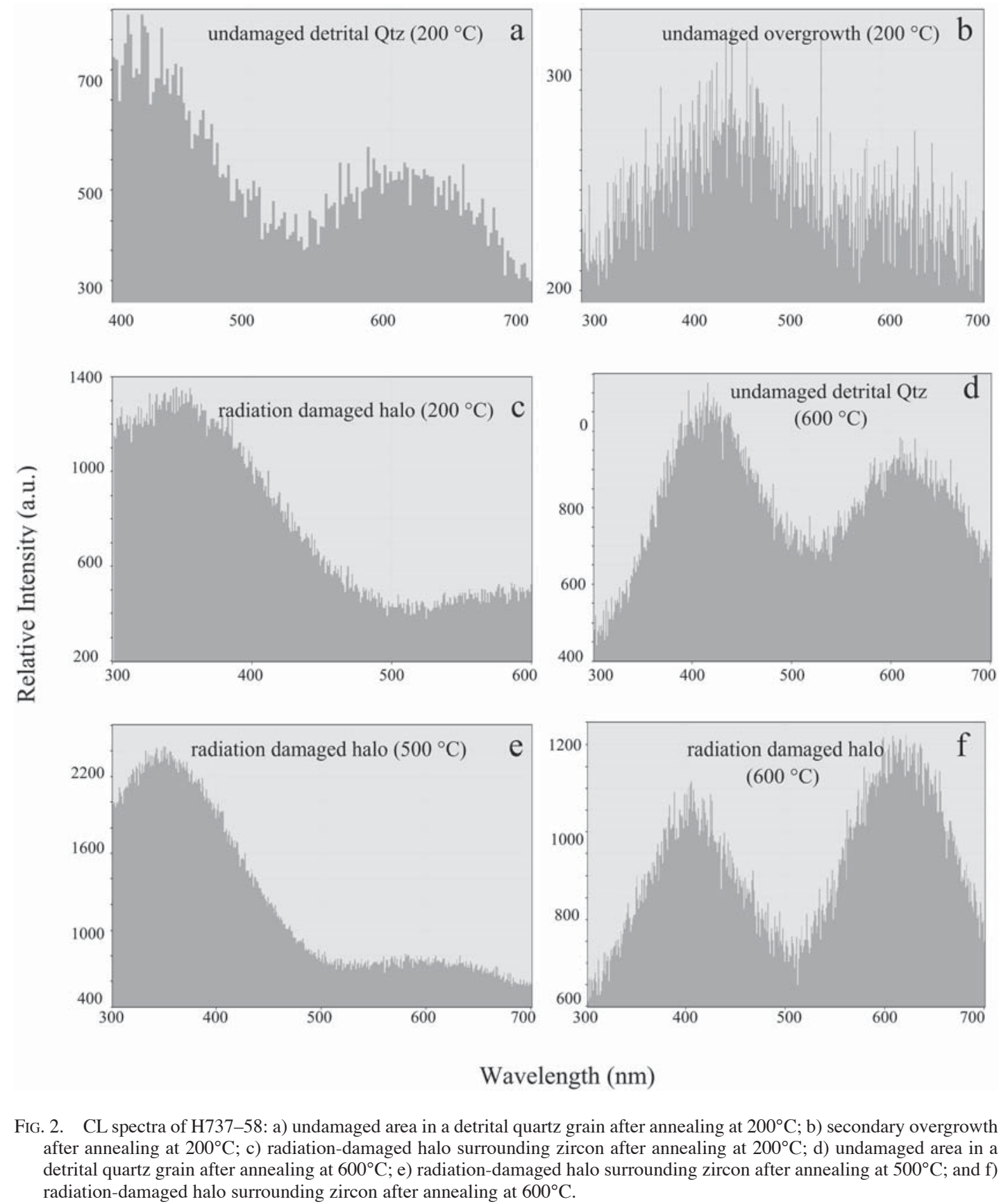




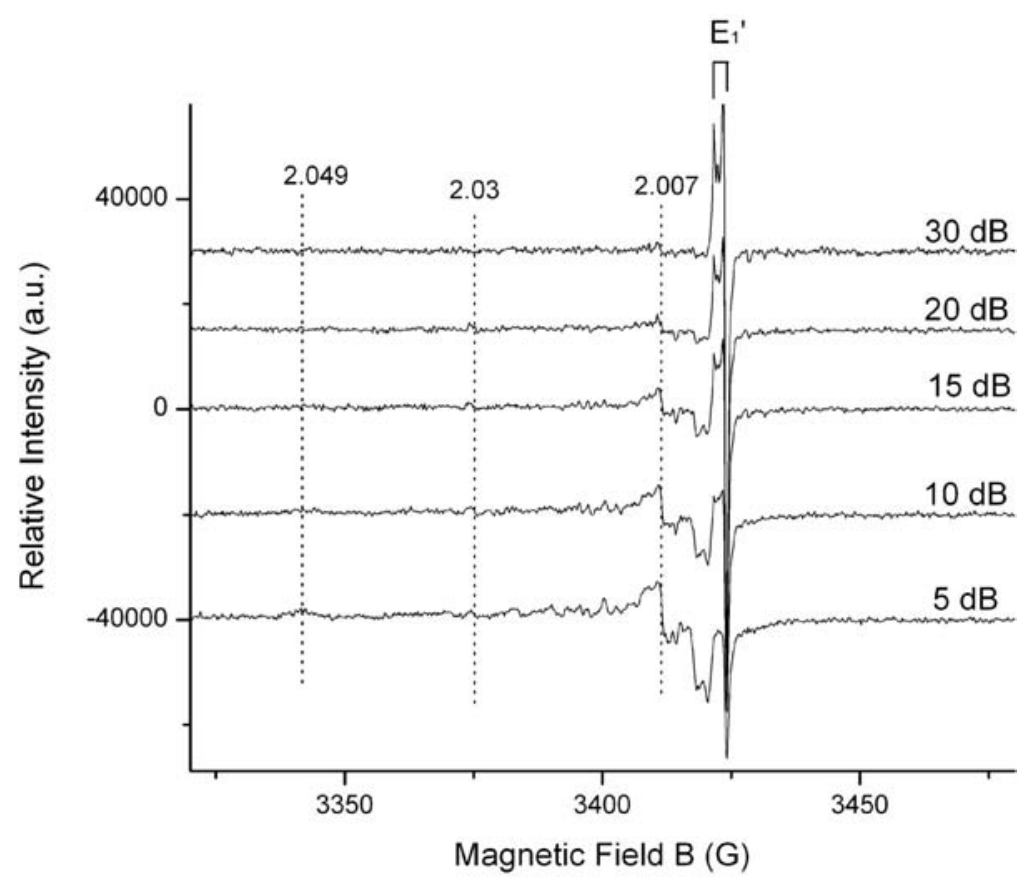

FIG. 3. Comparison of powder X-band EPR spectra of H737-58 without isochronal annealing, collected at room temperature and various microwave powers (30 to $5 \mathrm{~dB}$ ). Also the effective $g$ values of selected peaks and center $\mathrm{E}_{1}$ ' are labeled.

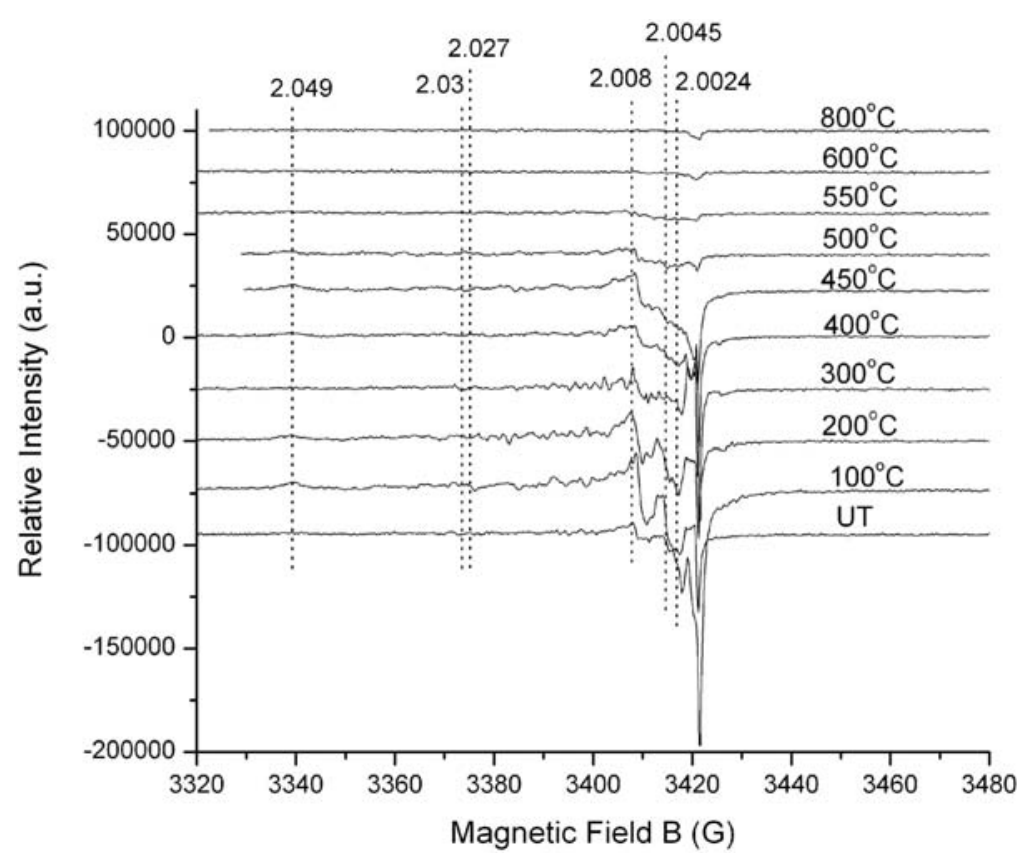

FIG. 4. Comparison of powder X-band EPR spectra of untreated sample H737-58 (UT) and after isochronal annealing at $100,200,300,400,450,500,550,600$ and $800^{\circ} \mathrm{C}$, collected at room temperature and microwave power of $10 \mathrm{~dB}$. 
$200^{\circ} \mathrm{C}$ spectra, at the same microwave powers (Fig. 4). However, the overall intensities decrease gradually and systematically from the $200^{\circ} \mathrm{C}$ to the 300,400 and $450^{\circ} \mathrm{C}$ spectrum (Fig. 4).

A comparison of these EPR spectra at different temperatures permits a possible correlation of the various peaks to specific paramagnetic centers. For example, the broad peak at $g=2.049$ varies systematically with two other broad peaks at $\mathrm{g}=2.008$ and 2.0024 (Fig. 4). These g values are closely comparable to those of a silicon vacancy-hole center $\mathrm{O}_{2}{ }^{3-} / M^{+}(M$ : $\mathrm{Li}$ and $\mathrm{Na}$; Mashkovtsev et al. 1978).

The broad EPR peak at $\mathrm{g}=\sim 2.008$ not only increases in intensity from untreated sample to $200^{\circ} \mathrm{C}$ but also becomes a well-resolved doublet at $200^{\circ} \mathrm{C}$ (Fig. 4). Similarly, the broad peak at $\mathrm{g}=\sim 2.005$ increases in intensity from untreated sample to $200^{\circ} \mathrm{C}$ and becomes a doublet at 100 and $200^{\circ} \mathrm{C}$. However, these peaks have different behavior at $300^{\circ} \mathrm{C}$. For example, the line at $\mathrm{g}=$ $\sim 2.005$ almost disappear at $300^{\circ} \mathrm{C}$, whereas the lines at $\mathrm{g}=\sim 2.008$ have decreased intensities but remain well resolved (Fig. 4). This result suggests that these peaks at $\mathrm{g}=\sim 2.005$ and $\sim 2.008$ most likely belong to different paramagnetic centers. In particular, the doublet with $g$ $=2.0050$ and 2.0040 is similar to those of the siliconvacancy hole center $\mathrm{O}_{2}{ }^{3-} / \mathrm{H}^{+}(\mathrm{II})\left(\mathrm{g}_{1}=2.0007, \mathrm{~g}_{2}=\right.$ 2.0042 and $g_{3}=2.0052 ;$ Mashkovtsev et al. 1978). The $\mathrm{g}_{1}=2.0007$ peak of this center is expected to overlap with the $\mathrm{E}_{1}$ ' center. Another similar silicon vacancy-hole center $\mathrm{O}_{2}{ }^{3-} / \mathrm{H}^{+}(\mathrm{I})\left(\mathrm{g}_{1}=2.0021, \mathrm{~g}_{2}=2.0074\right.$ and $\mathrm{g}_{3}=$ 2.0295; Mashkovtsev et al. 1978) is indicated by the $\mathrm{g}=\sim 2.03$ peak (Fig. 4). In addition, the characteristic doublet of the $\mathrm{E}_{1}$ center in the $100^{\circ} \mathrm{C}$ spectra is distorted (Fig. 4) and is probably attributable to interference from an unknown center with a $\mathrm{g}=\sim 2.0005$ peak, as suggested by spectral simulations (see below).

The 500 and $550^{\circ} \mathrm{C}$ spectra show further decrease in overall intensities relative to their low-T counterparts of the same microwave powers and are characterized by the disappearance of the $\mathrm{E}_{1}$ ' center (Fig. 4). The $\mathrm{O}_{2}{ }^{3} M^{+}$, $\mathrm{O}_{2}{ }^{3} \mathrm{H}^{+}(\mathrm{I})$ and $\mathrm{O}_{2}{ }^{3} \mathrm{H}^{+}(\mathrm{II})$ centers remain well resolved on the 500 and $550^{\circ} \mathrm{C}$ spectra, especially those obtained at high microwave power.

The $600^{\circ} \mathrm{C}$ spectrum is characterized by one broad peak of very low intensity at $\mathrm{g}=\sim 2.001$, whereas all other paramagnetic centers observed at lower temperatures disappear (Fig. 4). The line shape suggests that an isotropic paramagnetic center cannot be responsible for the broad peak at $g=\sim 2.001$. This $g$ factor is similar to the $\mathrm{g}_{1}$ values of two $\mathrm{O}_{2}^{-}$peroxy centers in artificially irradiated amorphous $\mathrm{SiO}_{2}$ and $\alpha$-quartz $\left(\mathrm{PR}_{1}: \mathrm{g}_{1}=\right.$ $2.0018, \mathrm{~g}_{2}=2.0078$ and $\mathrm{g}_{3}=2.067 ; \mathrm{PR}_{2}: \mathrm{g}_{1}=2.0020$, $\mathrm{g}_{2}=2.0085$ and $\mathrm{g}_{3}=2.027$; Griscom 1989). Therefore, the aforementioned doublet at $\mathrm{g}=\sim 2.008$ may be attributable to the peroxy centers. Moreover, the presence of the characteristic peak at $\mathrm{g}_{3}=2.027$ on the low- $\mathrm{T}$ spectra and the high-microwave-power $550^{\circ} \mathrm{C}$ spectra
(Fig. 4) suggests that peroxy center $\mathrm{PR}_{2}$ is present in H737-58.

Dependence of paramagnetic centers on microwave power at $200^{\circ} \mathrm{C}$

Figure 5 presents the $200^{\circ} \mathrm{C}$ EPR spectra, which have the highest overall intensities (see above), to illustrate the dependence of individual paramagnetic centers on microwave power (i.e., saturation behavior). Center $\mathrm{E}_{1}$ ' decreases in intensity with increasing microwave power and is saturated at $5 \mathrm{~dB}$. All other centers, however, increase in intensity with increasing microwave power up to about $5 \mathrm{~dB}$ and then decrease in intensity with a further increase in microwave power. For example, the two peroxy centers appear as a broad peak at $\mathrm{g}=\sim 2.008$ at $20 \mathrm{~dB}$ but are well resolved at 15 $\mathrm{dB}$ and higher microwave powers (Fig. 5). The $\mathrm{O}_{2}{ }^{3-} / M^{+}$, $\mathrm{O}_{2}{ }^{3-} / \mathrm{H}^{+}(\mathrm{I})$ and $\mathrm{O}_{2}{ }^{3-} / \mathrm{H}^{+}(\mathrm{II})$ also become better resolved at $10 \mathrm{~dB}$ and higher microwave powers.

The $\sim 200$ and $\sim 150 \mathrm{~K}$ EPR spectra

The $\sim 200$ and $\sim 150 \mathrm{~K}$ EPR spectra of H737-58 without isochronal annealing (Fig. 6) provide further information on the identification of paramagnetic centers. For example, the broad peak at $\mathrm{g}=\sim 2.005$ appears to decrease in intensity from $\sim 200$ to $\sim 150 \mathrm{~K}$, whereas the peak at $\mathrm{g}=\sim 2.007$ shows a marked increase in intensity in this temperature range. This contrasting behavior supports results from isochronal annealing experiments that these two peaks belong to different paramagnetic centers.

\section{EPR spectra of $H F$-treated materials}

Figure 7 shows that all paramagnetic centers decrease significantly in intensity after each step of $\mathrm{HF}$ treatments. However, center $\mathrm{E}_{1}$ ' shows a smaller decrease in intensity and becomes better resolved relative to the other centers (Fig. 7). The small decrease in intensity of center $E_{1}$ ' is readily attributable to reduction in sample size (i.e., from $\sim 80$ to $\sim 50 \mathrm{mg}$ ) after HF treatments. Therefore, center $\mathrm{E}_{1}$ ' is probably distributed evenly throughout the quartz grains. Other paramagnetic centers are most likely concentrated in the radiation-damaged rims and fractures that were preferentially dissolved away during the HF treatments.

\section{Trace-element data from the ICP-MS analyses}

Our ICPMS analyses revealed that the quartz separates from H737-58 contain Ti (41 $\pm 0.98 \mathrm{ppm}), \mathrm{Mn}$ $(0.97 \pm 0.18 \mathrm{ppm}), \mathrm{Cu}(03.8 \pm 0.05 \mathrm{ppm}), \mathrm{Zn}(49 \pm$ $1.89 \mathrm{ppm}), \mathrm{Ge}(0.95 \pm 0.06 \mathrm{ppm}), \mathrm{Sr}(9 \pm 0.2 \mathrm{ppm}), \mathrm{Zr}$ $(12 \pm 0.05 \mathrm{ppm}), \mathrm{Al}(590 \pm 1.2 \mathrm{ppm}), \mathrm{Ce}(4.4 \pm 0.02$ ppm), $\mathrm{Pb}(13 \pm 0.03 \mathrm{ppm})$, Th $(0.69 \pm 0.01 \mathrm{ppm})$ and 


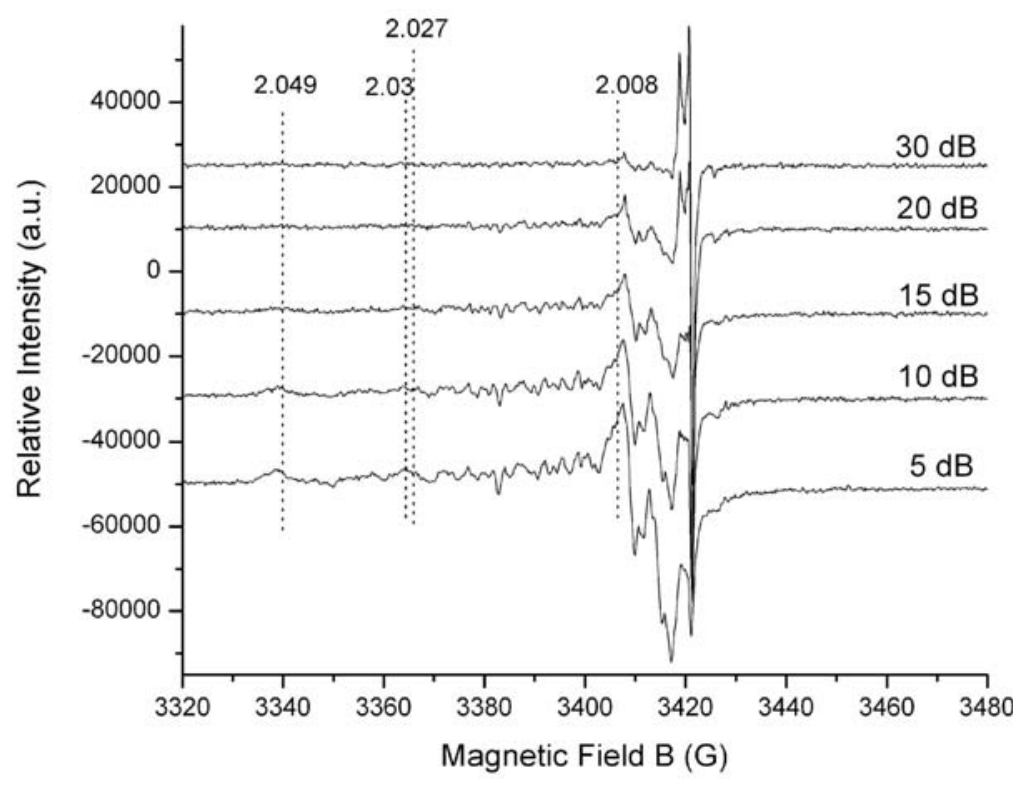

FIG. 5. Comparison of powder X-band EPR spectra of H737-58 after isochronal annealing at $200^{\circ} \mathrm{C}$, collected at room temperature and various microwave powers (30 to $5 \mathrm{~dB})$.

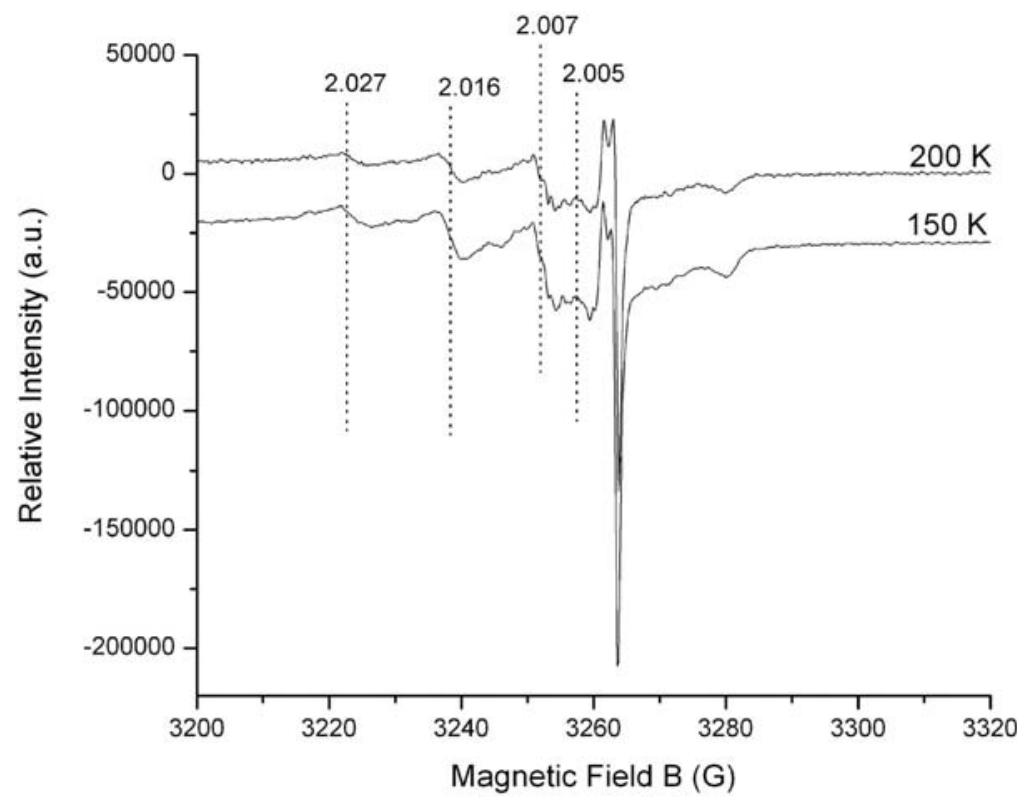

FIG. 6. Comparison of powder X-band EPR spectra of H737-58, collected at $\sim 200 \mathrm{~K}$ and $\sim 150 \mathrm{~K}$, and microwave power of $15 \mathrm{~dB}$. 


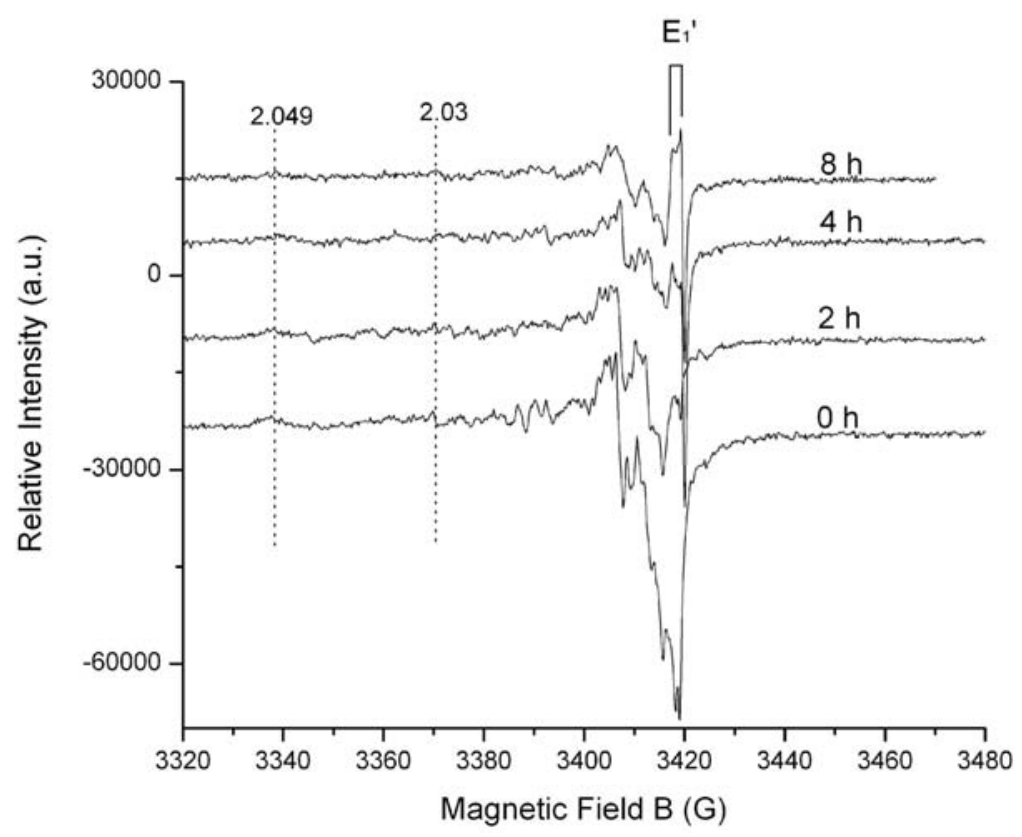

FIG. 7. Comparison of X-band EPR spectra of H737-58 before and after sequential HF treatments. Note that all spectra were collected at a microwave power of $10 \mathrm{~dB}$. Also labeled is center $\mathrm{E}_{1}$ '.

$\mathrm{U}(167 \pm 0.01 \mathrm{ppm})$. The most salient feature of the trace-element data in this sample is the significant $\mathrm{Al}$ content, which is a common constituent in natural quartz (Weil 1984, Demars et al. 1996). Lithium was sought but is below the detection limit of $2.3 \mathrm{ppm}$. Titanium in H737-58 may be present in the quartz structure (Weil 1984, Plötze \& Wolf 1996), although rutile has been observed as a common inclusion in quartz grains of this sample and may not be completely eliminated during mineral separation. The presence of significant amounts of $\mathrm{U}, \mathrm{Pb}, \mathrm{Zr}$ and $\mathrm{Zn}$ is also likely attributable to contamination from mineral inclusions.

\section{DISCUSSION}

\section{Interpretation of powder X-band EPR spectra}

Our X-band EPR spectra of H737-58 are very similar to those of shock-metamorphosed quartz reported by Serebrennikov et al. (1982), who also reported thermoluminescence (TL) at 365, 470 and $610-680 \mathrm{~nm}$. They interpreted their EPR spectra to arise from a combination of the well-known $\mathrm{E}_{1}$ ' center and five other oxygen-hole centers with similar g factors. However, their identification of the five oxygen-hole centers was based solely on the galues taken from the spectra. These authors noted that two of the five proposed oxygen-hole centers have g values close to the silicon vacancy-hole centers $\mathrm{O}_{2}{ }^{3-} / M^{+}$and $\mathrm{O}_{2}{ }^{3-} / \mathrm{H}^{+}(\mathrm{I})$ reported by Mashkovtsev et al. (1978).

Serebrennikov et al. (1982) attributed the proposed oxygen-hole centers to vacancies associated with dislocations induced by shock metamorphism. Our X-band EPR measurements show that a sandstone sample of mixed quartz, coesite and stishovite from the Meteor Crater, Arizona, is EPR-silent. Serebrennikov et al. (1982) observed the parmagnetic centers in the shockmetamorphosed quartz only after X-ray irradiation. Therefore, their proposed oxygen-hole centers, whether related to shock metamorphism or not, are activated by $\mathrm{X}$-ray irradiation.

Götze et al. (1999) reported another similar Xband EPR spectrum for a red agate, from Lauterbach, Germany and obtained the $\mathrm{g}$ factors for two paramagnetic centers which, following Bershov et al. (1978) and Serebrennikov et al. (1982), were assigned to the $\mathrm{O}^{-}$and $\mathrm{O}_{2}{ }^{3-}$ centers. A comparison of their simulated and observed spectra shows significant discrepancies (Plötze, pers. commun. 2004), pointing to the presence of additional paramagnetic centers. Moreover, the $\mathrm{g}$ factors of their $\mathrm{O}^{-}$center are similar to those of the $\mathrm{O}_{2}{ }^{3-}-$ $M^{+}$center (Mashkovtsev et al. 1978), the Ge trappedhole center in quartz (Hayes \& Jenkin 1986), and the self-traped hole $\left(\mathrm{STH}_{1}\right)$ in amorphous $\mathrm{SiO}_{2}(\mathrm{Griscom}$ 
1989), whereas the $\mathrm{g}$ factors of their $\mathrm{O}_{2}{ }^{3-}$ center are indistinguishable from those of the peroxy radical $\mathrm{PR}_{2}$ (Griscom 1989).

Our spectral simulations included the following six known paramagnetic defects: $\mathrm{E}_{1}{ }^{1}, \mathrm{O}_{2}{ }^{3-} / \mathrm{H}^{+}(\mathrm{I})$, $\mathrm{O}_{2}{ }^{3-} / \mathrm{H}^{+}(\mathrm{II}), \mathrm{O}_{2}{ }^{3-} / M^{+}, \mathrm{PR}_{1}$ and $\mathrm{PR}_{2}$ (Table 1). Spectral simulations confirm the presence of six paramagnetic centers in sample H737-58 (Table 1, Fig. 8). All of these centers have been reported previously in crystalline or amorphous $\mathrm{SiO}_{2}$, but were invariably from artificially irradiated materials (e.g., Weeks 1956, Friebele et al. 1979, Griscom \& Friebele 1981, Griscom 1989). Therefore, the presence of these paramagnetic centers in H737-58 represents the first example documented in naturally irradiated quartz. It is noteworthy that McMorris (1970) reported similar EPR spectra of quartz from sandstones and attributed them to fossil alpha damage. However, the EPR spectra reported by McMorris (1970) only allowed the identification of the $\mathrm{E}_{1}$ ' center. Our EPR spectra of the HF-treated samples also confirmed that all paramagnetic centers, except for $E_{1}$ ', are concentrated largely in the alpha-particledamaged patches and rims.
Table 1 shows that the naturally occurring paramagnetic centers in sample H737-58 have similarities and significant differences in thermal properties and saturation behaviors to their respective counterparts in artificially irradiated materials. For example, Friebele et al. (1979) reported that the peroxy centers remain stable after annealing to $700^{\circ} \mathrm{C}$ (see also Griscom \& Friebele 1981, Griscom 1989), similar to the preservation of these centers to $700^{\circ} \mathrm{C}$ in $\mathrm{H} 737-58$ (Table 1). Also, the saturation behavior of the $\mathrm{E}_{1}$ ' center is similar to that reported in literature, but the presence of this center on the $450^{\circ} \mathrm{C}$ spectrum is unusual in comparison with its commonly reported annealing temperature of 360-380 ${ }^{\circ} \mathrm{C}$ (Ikeya 1993). Similarly, Mashkovtsev et al. (1978) reported that the silicon vacancy-hole centers are stable only up to $300-400^{\circ} \mathrm{C}$, whereas the $\mathrm{O}_{2}{ }^{3-} / \mathrm{H}^{+}(\mathrm{I})$, $\mathrm{O}_{2}{ }^{3-} / \mathrm{H}^{+}(\mathrm{II})$ and $\mathrm{O}_{2}{ }^{3-} / M^{+}$centers are all detected on the high-microwave-power $550^{\circ} \mathrm{C}$ spectra of H737-58. It remains uncertain whether the high temperatures of annealing of these radiation-damage-induced paramagnetic centers in H737-58 are attributable to high dosage of natural irradiation in this sample.

TABLE 1. SUMMARY OF PARAMAGNETIC. DEFECTS IN SAMPLE H737-58

\begin{tabular}{|c|c|c|c|c|c|c|c|c|}
\hline \multirow[t]{2}{*}{ Defect } & \multicolumn{2}{|c|}{$\mathrm{g}$ factors } & \multirow[t]{2}{*}{ Structural model } & \multicolumn{2}{|c|}{ Saturation behavior } & \multicolumn{2}{|c|}{ Thermal properties } & \multirow[t]{2}{*}{ s Ref } \\
\hline & $\begin{array}{c}\text { Previous } \\
\text { studies }\end{array}$ & $\begin{array}{l}\text { This } \\
\text { study }\end{array}$ & & $\begin{array}{c}\text { Previous } \\
\text { studies }\end{array}$ & $\begin{array}{l}\text { This } \\
\text { study }\end{array}$ & $\begin{array}{c}\text { Previous } \\
\text { studies }\end{array}$ & $\begin{array}{l}\text { This } \\
\text { study }\end{array}$ & \\
\hline$E_{i}^{\prime}$ & $\begin{array}{l}2.00178 \\
2.0005 \\
2.00033\end{array}$ & $\begin{array}{l}2.00178 \\
2.0005 \\
2.00033\end{array}$ & $\begin{array}{l}\text { an unpaired electron in an } \\
\mathrm{O} \text { vacancy, where the } \\
\text { electron occupies a dangling } \\
\mathrm{sp}^{3} \text { hybrid orbital of } \mathrm{Si} \\
\text { bonded to three } \mathrm{O} \text { atoms }\end{array}$ & $\begin{array}{l}\text { saturated } \\
\text { at } 100 \\
\mathrm{~mW}\end{array}$ & $\begin{array}{l}\text { saturated } \\
\text { at } 100 \\
\mathrm{~mW}\end{array}$ & $\begin{array}{l}\text { annealed } \\
\text { at } \sim 400\end{array}$ & $\begin{array}{l}\text { present } \\
\text { up to } \\
500\end{array}$ & $\begin{array}{r}1,2 \\
3\end{array}$ \\
\hline Peroxy 1 & $\begin{array}{l}2.067 \\
2.0078 \\
2.0018\end{array}$ & $\begin{array}{l}2.067 \\
2.0076 \\
2.001\end{array}$ & $\begin{array}{l}\text { a hole trapped by an } \mathrm{O}_{2} \\
\text { molecule at an } \mathrm{O}^{2-} \text { site } \\
\text { in the form of } \mathrm{Si}-\mathrm{O}-\mathrm{O}\end{array}$ & no data & $\begin{array}{l}\text { active at } \\
159 \mathrm{~mW}\end{array}$ & $\begin{array}{l}\text { present } \\
\text { at } 700\end{array}$ & $\begin{array}{l}\text { present } \\
\text { at } 800\end{array}$ & $\begin{array}{r}3,4 \\
5,6 \\
7\end{array}$ \\
\hline Peroxy 2 & $\begin{array}{l}2.027 \\
2.0085 \\
2.0020\end{array}$ & $\begin{array}{l}2.027 \\
2.0085 \\
2.0018\end{array}$ & $\begin{array}{l}\text { a hole trapped by an } \mathrm{O}_{2} \\
\text { molecule at an } \mathrm{O}^{3-} \text { site } \\
\text { in the form of } \mathrm{Si}-\mathrm{O}-\mathrm{O}\end{array}$ & no data & $\begin{array}{l}\text { active at } \\
159 \mathrm{~mW}\end{array}$ & $\begin{array}{l}\text { present } \\
\text { at } 700\end{array}$ & $\begin{array}{l}\text { present } \\
\text { at } 800\end{array}$ & 5 \\
\hline $\mathrm{O}_{2}^{3-} / \mathrm{M}$ & $\begin{array}{l}2.049 \\
2.0076 \\
2.0024\end{array}$ & $\begin{array}{l}2.0495 \\
2.0076 \\
2.0024\end{array}$ & $\begin{array}{l}\text { involving a Si vacancy that } \\
\text { leads to a hole trapped by } \\
\text { two } \mathrm{O} \text { atoms, forming } \mathrm{O}_{2}{ }^{3-} \text {, } \\
\text { with } M\left(\mathrm{Li}^{+} \text {or } \mathrm{Na}^{+}\right) \text {as } \\
\text { charge compensators }\end{array}$ & no data & $\begin{array}{l}\text { active at } \\
159 \mathrm{~mW}\end{array}$ & no data & $\begin{array}{l}\text { present } \\
\text { up to } \\
500 \\
\text { anncaled } \\
\text { at } 600\end{array}$ & 8 \\
\hline $\mathrm{O}_{2}^{3-} / \mathrm{H}^{+}(\mathrm{I})$ & $\begin{array}{l}2.0295 \\
2.0074 \\
2.0021\end{array}$ & $\begin{array}{l}2.0285 \\
2.0074 \\
2.0021\end{array}$ & $\begin{array}{l}\text { involving a } \mathrm{Si} \text { vacancy that } \\
\text { leads to a hole trapped by } \\
\text { two } \mathrm{O} \text { atoms, forming } \mathrm{O}_{2}{ }^{3-} \text {, } \\
\text { with } \mathrm{H}^{+} \text {as a charge } \\
\text { compensator }\end{array}$ & no data & $\begin{array}{l}\text { active at } \\
159 \mathrm{~mW}\end{array}$ & no data & $\begin{array}{l}\text { present } \\
\text { up to } \\
500 \\
\text { annealed } \\
\text { at } 600\end{array}$ & 8 \\
\hline $\mathrm{O}_{2}{ }^{3-} / \mathrm{H}(\mathrm{II})$ & $\begin{array}{l}2.0052 \\
2.0042 \\
2.0007\end{array}$ & $\begin{array}{l}2.00528 \\
2.004 \\
2.0007\end{array}$ & $\begin{array}{l}\text { involving a Si vacancy that } \\
\text { leads to a hole trapped by } \\
\text { two } \mathrm{O} \text { atoms, forming } \mathrm{O}_{2}{ }^{3-} \text {, } \\
\text { with } \mathrm{H}^{+} \text {as a charge } \\
\text { compensator }\end{array}$ & no data & $\begin{array}{l}\text { active at } \\
159 \mathrm{~mW}\end{array}$ & no data & $\begin{array}{l}\text { present } \\
\text { up to } \\
500 \\
\text { annealed } \\
\text { at } 600\end{array}$ & 8 \\
\hline
\end{tabular}

References: 1 Feigle \& Anderson (1970), 2 Silsbee (1961), 3 lkeya (1993), 4 Griscom (1978), 5 Griscom (1989), 6 Friebele et al. (1979), 7 Weeks et al. (1956), 8 Mashkovtsev et al. (1978). 
a

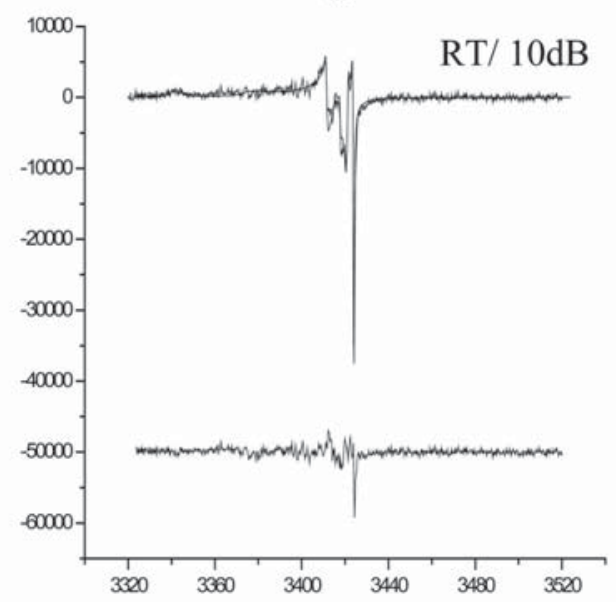

$\mathrm{c}$

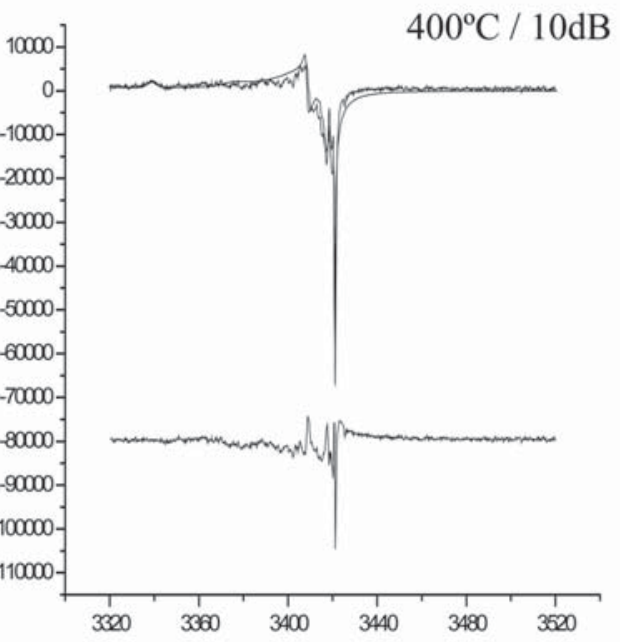

b

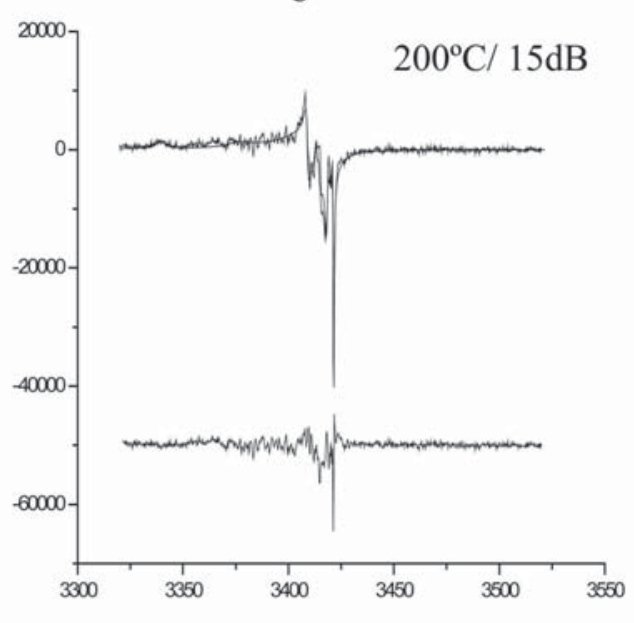

d

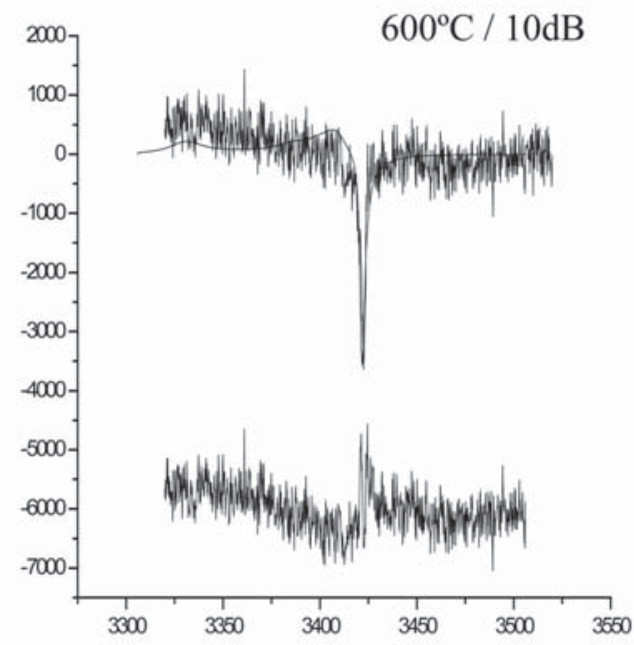

\section{Magnetic Field B (G)}

FIG. 8. Comparison of simulated and observed powder X-band EPR spectra of $\mathrm{H} 737-58$ at various temperatures and microwave powers: a) room temperature and $10 \mathrm{~dB}$; b) $200^{\circ} \mathrm{C}$ and $15 \mathrm{~dB}$; c) $400^{\circ} \mathrm{C}$ and $10 \mathrm{~dB}$; and d) $600^{\circ} \mathrm{C}$ and $10 \mathrm{~dB}$. Spectral simulations for a), b) and c) included the following six centers: 1) oxygen vacancy center $\left.\mathrm{E}_{1} 2-3\right)$ peroxy centers $\left(\mathrm{PR}_{1}\right.$, Griscom \& Friebele 1981; $\mathrm{PR}_{2}$ Griscom 1989), 4-6) silicon vacancy hole centers $\left[\mathrm{O}_{2}{ }^{3-} / \mathrm{H}^{+}(\mathrm{I}), \mathrm{O}_{2}{ }^{3-} / \mathrm{H}^{+}(\mathrm{II})\right.$ and $\mathrm{O}_{2}{ }^{3-} / M^{+}$, Mashkovtsev et al. 1978). Note that only two peroxy centers are needed to simulate the spectra at and above $600^{\circ} \mathrm{C}$. Also shown are the difference spectra. A notable signal with an effective $\mathrm{g}=2.001$ is visible on all difference spectra and is probably attributable to an isotropic center of this $g$ value reported by Serebrennikov et al. (1982). 
Correlations between $C L$ spectra and paramagnetic centers

Numerous previous investigations have hypothesized that various types of luminescence in quartz are related to structural defects in this mineral (Stevens Kalceff \& Phillips 1995, Götze et al. 2001, and references therein). Most of the proposed structural defects (e.g., Götze et al. 2001) are paramagnetic or become paramagnetic after artificial irradiation treatment and, hence, can be characterized by EPR spectroscopy. However, there have been relatively few examples of integrated CL and EPR studies in the past (e.g., Plötze \& Wolf 1996, Götze et al. 1999, 2001, 2005). Also, correlations between CL emission bands and paramagnetic defects identified by EPR are difficult.

In the present study, we documented the CL spectra of radiation-damaged areas in quartz before and after a series of isochronal annealing experiments. Also, our EPR measurements on the isochronally annealed samples allowed a detailed documentation of the thermal properties of the paramagnetic defects associated with natural alpha-particle-induced radiation damages in quartz. These results allow us to correlate the characteristic CL emission bands and specific paramagnetic defects in quartz on the basis of their thermal behavior (Table 1). The characteristic $\sim 350 \mathrm{~nm}$ peak associated with the CL halos and rims of H737-58 is annealed below $600^{\circ} \mathrm{C}$ (Fig. 2e). Similarly, the silicon vacancy-oxygen hole centers $\left[\mathrm{O}_{2}{ }^{3-} / M^{+}, \mathrm{O}_{2}{ }^{3-} / \mathrm{H}^{+}(\mathrm{I})\right.$ and $\left.\mathrm{O}_{2}{ }^{3-} / \mathrm{H}^{+}(\mathrm{II})\right]$ are associated with radiation damages and are annealed between 550 and $600^{\circ} \mathrm{C}$. Therefore, one (or recombinations) of these oxygen holes centers may be responsible for the ultraviolet $\mathrm{CL}$ in the radiationdamaged halos and rims. Center $\mathrm{E}_{1}$ ', on the other hand, is not restricted to the radiation-damaged areas and is annealed at $\sim 500^{\circ} \mathrm{C}$ and, therefore, is unlikely to be responsible for this ultraviolet CL. Powder X-band EPR experiments of annealed samples also show that the peroxy radicals are the only paramagnetic centers stable at and above $600^{\circ} \mathrm{C}$. It is possible, therefore, that the peroxy centers may be responsible for the $\sim 620-650$ $\mathrm{nm}$ CL in the radiation-damaged halos and rims, which remains active up to at least $800^{\circ} \mathrm{C}$ but is annealed out at $900^{\circ} \mathrm{C}$

Rink et al. (1993) reported a $\sim 330 \mathrm{~nm}$ thermoluminescene (TL) band in quartz from a pegmatite and attributed it to either the presence of feldspar impurities or oxygen vacancies. The present study shows that the oxygen-vacancy center $E_{1}$ ' is unlikely to be directly responsible for the characteristic ultraviolet $\mathrm{CL}$ in the radiation-damaged area. Demars et al. (1996) reported a $~ 340 \mathrm{~nm}$ CL peak in sandstone samples from the Paris Basin and attributed it to the $\left[\mathrm{AlO}_{4} / \mathrm{Li}\right]^{+}$center. Our ICP-MS analysis of H737-58 showed that $\mathrm{Al}$ is a significant trace element, but $\mathrm{Li}$ was below its detection limit. The absence of the $\left[\mathrm{AlO}_{4} / \mathrm{Li}\right]^{+}$center in our Xband EPR spectra is probably attributable to the fact that this center is detectable only below $35 \mathrm{~K}$. However, the $\left[\mathrm{AlO}_{4} / \mathrm{Li}\right]^{+}$center is expected to be distributed throughout the volume of the quartz grains and, hence, is unlikely to be responsible for the $\sim 350 \mathrm{~nm}$ CL that is restricted to the radiation-damaged halos and rims (Fig. 2). The $\left[\mathrm{TiO}_{4} / \mathrm{Li}\right]^{+}$center proposed by Plötze \& Wolf (1996), which is readily detectable by EPR at room temperature but is not observed in H737-58, is also unlikely to be responsible for the $\sim 350 \mathrm{~nm} \mathrm{CL}$ in the radiation-damaged halos and rims.

Götze et al. (2001) attributed the radiation-damagedinduced $\sim 650 \mathrm{~nm}$ CL in the Witwatersrand quartz to nonbridging oxygen-hole centers (NBOHC), with several precursors (such as hydroxyl group and peroxy linkages; $c f$. Stevens Kalceff \& Phillips 1995). Luff \& Townsend (1990) observed that the $650 \mathrm{~nm} \mathrm{CL}$ in synthetic quartz grows with radiation dose and that the damage is not recoverable once the electron beam is removed. These observations led Luff \& Townsend (1990) to suggest that the $\sim 650 \mathrm{~nm} \mathrm{CL}$ is related to a permanent defect such as oxygen vacancy centers. Siegel \& Marrone (1981) and Rémond et al. (1992) suggested that the $\sim 620-650 \mathrm{~nm}$ photoluminescence (PL) and CL are probably related to oxygen hole centers. Our study shows that the $\sim 620-650 \mathrm{~nm} \mathrm{CL}$ in the radiation-damaged halos and rims remain active to at least $800^{\circ} \mathrm{C}$, whereas most paramagnetic centers including oxygen vacancy and silicon vacancy-hole centers are all annealed below $600^{\circ} \mathrm{C}$. $\mathrm{NBOHC}$, on the other hand, is not observed in H737-58 and is known to be unstable above $500^{\circ} \mathrm{C}$ (Stapelbroek et al. 1979). Therefore, NBOHC or oxygen-vacancy centers cannot be responsible for the radiation-damage-induced CL at $\sim 620-650 \mathrm{~nm}$.

\section{Formation of peroxy centers in the Athabasca quartz.}

The present discovery of the peroxy centers in the Athabasca quartz is particularly noteworthy for the following two reasons. First, this is the first report of peroxy centers in natural quartz. Second, these peroxy centers are most likely responsible for the characteristic red CL in the radiation-damaged quartz. Similar to previous reports of peroxy radicals in neutron- and $\gamma$-irradiated fused silica (Friebele et al. 1979, Griscom \& Friebele 1981, Griscom 1989), our HF experiments demonstrate that these centers in the Athabasca quartz are concentrated in the radiation-damaged areas. Therefore, the origin of these peroxy centers in the Athabasca quartz is most likely related to nuclear radiation processes in this uranium-mineralized basin.

Peroxide in natural minerals is rare and has been reported only recently in two uranyl minerals: studtite and metastudtite (Burns \& Hughes 2003, HughesKobatko et al. 2003). Studtite and metastudtite occur in close association with other uranium minerals (e.g., uraninite) in nature and have been reported to 
be important products of alteration of nuclear waste (Sattonnay et al. 2001, Amme 2002, Burns \& Hughes 2003). Hughes-Kobatko et al. (2003, and reference herein) suggested that studtite and metastudtite might grow by incorporating peroxide created from alpha radiolysis of water. By analogy, the peroxy centers in the Athabasca quartz, particularly those from the high-grade McArthur River uranium deposit, might have formed first from alpha radiolysis of $\mathrm{H}_{2} \mathrm{O}$ (i.e., U-bearing mineralization fluids) and were then incorporated into the damaged areas by diffusion (i.e., promoted by radiation damage of the quartz structure). Alternatively, the peroxy centers in the Athabasca quartz might have formed from alpha radiolysis of $\mathrm{H}_{2} \mathrm{O}$ already present in the damaged areas, where alpha radiolysis is most likely related to U- and Th-bearing mineral inclusions, and the $\mathrm{H}_{2} \mathrm{O}$ might occur in fluid inclusions in quartz or might have been incorporated into the damaged areas from grain boundaries.

\section{CONCLUSIONS}

Distinct CL in radiation-damaged halos, patches and rims in quartz grains has been documented from the McArthur River uranium deposit, Athabasca Basin, Saskatchewan. The CL spectra of the radiation-damaged halos, patches and rims are characterized by pronounced but broad bands in the ultraviolet $(\sim 350 \mathrm{~nm})$ and red $(\sim 620-650 \mathrm{~nm})$ regions. The ultraviolet $\mathrm{CL}$ persists to $500^{\circ} \mathrm{C}$ and is annealed out at $600^{\circ} \mathrm{C}$, whereas the red CL remains active at $800^{\circ} \mathrm{C}$ and is annealed out at $900^{\circ} \mathrm{C}$.

Detailed EPR experiments, particularly those from isochronal annealing experiments, allow the identification of six radiation-damage-induced paramagnetic centers (one oxygen-vacancy center $\mathrm{E}_{1}$ ', three silicon vacancy-hole centers and two peroxy centers). The EPR spectra of HF-treated materials show that the silicon vacancy-hole centers and the peroxy centers are concentrated in the alpha-particle-damaged patches and rims. Moreover, correlations between the CL spectra and the paramagnetic centers from the isochronal annealing experiments suggest that the silicon vacancy-hole centers are most likely responsible for the ultraviolet $\mathrm{CL}$, whereas the red CL is best attributed to the peroxy centers.

\section{ACKNOWLEDGEMENTS}

We thank Drs. Roger Mason and Grant Henderson for constructive reviews and helpful suggestions, and D.F. Howarth (EPR), J.Z. Fan (ICPMS) and I. Coulson (CL spectra) for analytical assistance. Financial support for this study was provided by the Cameco Corporation and an NSERC Collaborative Research and Development (CRD) grant to Yuanming Pan and J.A. Weil.

\section{REFERENCES}

Amme, M. (2002): Contrary effects of the water radiolysis products $\mathrm{H}_{2} \mathrm{O}_{2}$ upon the dissolution of nuclear fuel in natural ground water and deionized water. Radiochim. Acta 90, 399-406

BAKER, E.B. \& OwEN, M.R. (1983): 800 threshold for cathodoluminescence in zircon and radiation-damage haloes in metaquartzite. Geol. Soc. Am., Abstr. Prog. 18, 532.

Bershov, LV., Krylova, M.D. \& SperanskiJ, A.V. (1978): The electron hole centers $\mathrm{O} \mathrm{Al}$ and $\mathrm{Ti}^{3+}$ as indicators for temperature conditions during regional metamorphism. Izv. Akad. Nauk SSSR, Ser. Geol., 113-7 (in Russ.).

BragG, W.H. \& Kleeman, R. (1905): Alpha particles or radium, and their loss of range passing through various atoms and molecules. Phil. Mag. 10, 318-334.

Bruhn, F., Bruckschenm P., Meijer, J., Stephan, A., RichTER, D.K. \& VeIzer, J. (1996): Cathodoluminescence investigations and trace-element analyses of quartz by micro-PIXE: implications for diagenetic and provenance studies in sandstones. Can. Mineral. 34, 1223-1232.

Burns, P.C. \& Hughes, K.-A. (2003): Studtite, $\left[\left(\mathrm{UO}_{2}\right)\left(\mathrm{O}_{2}\right)\right.$ $\left.\left(\mathrm{H}_{2} \mathrm{O}\right)_{2}\right] \mathrm{H}_{2} \mathrm{O}$ : the first structure of a peroxide mineral. Am. Mineral. 88, 1165-1168.

Demars, C., Pagel, M., Deloule, E. \& Blanc, P. (1996): Cathodoluminescence of quartz from sandstones: interpretation of the UV range by determination of trace element distributions and fluid-inclusion P-T-X properties in authigenic quartz. Am. Mineral. 81, 891-901.

Feigl, F.J. \& Anderson, J.H. (1970): Defects in crystalline quartz: electron paramagnetic resonance of $E^{\prime}$ vacancy centers associated with germanium impurities. J. Phys. Chem. Solids 31, 575-596.

Friebele, E.J., Griscom, D.L., Stapelbroek, M. \& Weeks, R.A. (1979): Fundamental defect centers in glass: the peroxy radical in irradiated, high-purity, fused silica. Phys. Rev. Lett. 42, 1346-1349.

Götze, J., Plötze, M., Fuchs, H. \& Habermann, D. (1999): Defect structure and luminescence behavior of agate - results of electron paramagnetic resonance (EPR) and cathodoluminescence (CL) studies. Mineral. Mag. 63,149163.

$$
\&
$$

(2001): Origin, spectral characteristics and practical applications of the cathodoluminescence (CL) of quartz - a review. Mineral. Petrol. 71, 225-250.

\& Trautmann, T. (2005): Structure and luminescence characteristics of quartz from pegmatites. Am. Mineral. 90, 13-21.

GRISCOM, D.L. (1978): Defects in amorphous insulators, $J$. Non-Crystal. Solids 31, 241-266. 
(1989): Self-trapped holes in amorphous silicon dioxide Phys. Rev. B 40, 4224-4228.

\& Friebele, E.J. (1981): Fundamental defect centers in glass: ${ }^{29} \mathrm{Si}$ hyperfine structure of the nonbridging oxygen hole center and the peroxy radical in $\alpha-\mathrm{SiO}_{2}$. Phys. Rev. B 24, 4896-4898.

Hanusiak, W.M. \& White, E.W. (1975): SEM cathodoluminescence for characterization of damaged and undamaged $\alpha$-quartz in respirable dusts. Scan. Elec. Micros., 125131 .

HAYES, W. \& JENKIN, J.T.L. (1986): Charge trapping properties of germanium in crystalline quartz. J. Phys. C: Solid State Phys. 19, 6211-6219.

Hughes-Kubatko, K.-A., Helean, K.B, Navrotsky, A. \& BuRns, P.C. (2003): Stability of peroxide-containing uranyl minerals. Science 302, 1191-1193.

IKeya, M. (1993): New Applications of Electron Spin Resonance: Dating, Dosimetry, and Spectroscopy. World Scientific, Singapore.

Jani, M.G., Bossoli, R.B. \& Halliburton, L.E. (1983): Further characterization of the $\mathrm{E}_{1}$ ' center in crystalline $\mathrm{SiO}_{2}$. Phys. Rev. B. 27, 2285-2293.

Komuro,K., Horikawa, Y. \& Toyoda, S. (2002): Development of radiation-damage halos in low- quartz: cathodoluminescence measurements after $\mathrm{He}^{+}$ion implantation. Mineral. Petrol. 76, 261-266.

LuFF, B.J. \& TownsEnD, P.D. (1990): Cathodoluminescence of synthetic quartz. J. Phys. Condens. Matter 2, 8089-8097.

Mashrovtsev, R.I., Scherbakova, M.Ya. \& Solntsev, V.P. (1978): EPR of radiation oxygen hole centers in $\alpha$-quartz. Tr. Inst. Geol. Geofiz., Akad. Nauk SSSR, Sib. Otd. 385 , 78-86 (in Russ.).

MCMorRIS, D.W. (1970): ESR detection of fossil alpha damage in quartz. Nature 226, 146-148.

Meunier, J.D., Sellier, E. \& Pagel, M. (1990): Radiationdamage rims in quartz from uranium-bearing sandstones. J. Sed. Petrol. 60, 53-58.

Mitchell, J.P. \& Denure, D.G. (1973): A study of SiO layers on Si using cathodoluminescence spectra. Solid State Electronics 16, 825-839.

Mombourquette, M.J., Weil, J.A. \& McGavin, D.G. (1996): EPR-NMR Users'Manual. Department of Chemistry, University of Saskatchewan, Saskatoon, Saskatchewan.

MorTON, R.D. (1978): Cathodoluminescence applied to uranium exploration. $\mathrm{Nucl}$. Spec. 11,1.

Nasdala, L., Wenzel, M., Andrut, M., Wirth, R. \& Blaum, P. (2001): The nature of radiohaloes in biotite: experimental studies and modeling. Am. Mineral. 86, 498-512.
OwEn, M.R. (1988): Radiation-damage haloes in quartz. Geo$\operatorname{logy} 16,529-532$.

PenNiston-Dorland, S.C. (2001): Illumination of vein quartz textures in a porphyry copper ore deposit using scanned cathodoluminescence: Grasberg Igneous Complex, Irian Jaya, Indonesia. Am. Mineral. 86, 652-666.

Plötze, M. \& Wolf, D. (1996): EPR- und TL-Spektren von Quartz: Bestrahlungsabhgigkeit der $\left[\mathrm{TiO}_{4}{ }^{-} / \mathrm{Li}^{+}\right]^{0}$-Zentren. Ber. Deutsch. Mineral. Gesellsch. 8, 217 (abstr.).

RAMAEKers, P. (1981): Hudsonian and Helikian basins of the Athabasca region, northern Saskatchewan. In Proterozoic Basins of Canada (F.H.A. Campbell, ed.). Geol. Surv. Can. Pap. 81-10, 219-233.

Ramseyer, K., Baumann, J., Matter, A. \& Mullis, J. (1988): Cathodoluminescence colours of $\alpha$-quartz. Mineral. Mag. 52, 669-677.

Rémond, G., Cesbron, F., Chapoulie, R., Ohnenstetter, D., Roques-Carmes, C. \& Schvoerer, M. (1992): Cathodoluminescence applied to the microcharacterization of mineral materials: a present status in experimentation and interpretation. Scann. Micros. 6, 23-68.

Rink, W.J., Rendell, H., Marseglia, E.A., Luff, B.J., \& TownsEnd, P.D. (1993) Thermoluminescence spectra of igneous quartz and hydrothermal vein quartz. Phys. Chem. Minerals 20, 353-361.

Serebrennikov, A.J., Valter, A.A., Mashkovtsev, R.I. \& ScherbAKOVA, M.YA. (1982): The investigation of defects in shock-metamorphosed quartz. Phys. Chem. Minerals 8, 155-157.

Siegel, G.H., JR. \& Marrone, M.J. (1981): Photoluminescence in as-drawn and irradiated silica optical fibers: an assessment of the role of nonbridging oxygen defect centers. J. Non-Cryst. Solids 45, 235-247.

SillsbeE, R.H. (1961): Electron spin resonance in neutronirradiated quartz. J. Appl. Phys. 32, 1459-1462.

Smith, J.V. \& Stenstrom, R.C. (1965): Electron-excited luminescence as a petrologic tool. J. Geol. 73, 627-635.

SPRUNT, E.S. (1981): Causes of quartz cathodoluminescence colours. Scan. Elec. Micros., 525-535.

Stapelbroek, M., Griscom, D.L., Friebele, E.J. \& Sigel, G.H., JR. (1979): Oxygen-associated trapped-hole centers in high-purity fused silica. J. Non-Cryst. Solids 32, 313 326.

Stevens Kalceff, M.A. \& Phillips, M.R. (1995): Cathodoluminescence microcharacterization of the defect structure of quartz. Phys. Rev. B 52, 3122-3134.

WEEKs, R.A. (1956): Paramagnetic resonance of lattice defects in irradiated quartz. J. Appl. Phys. 27, 1376-1381. 
WEIL, J.A. (1984): A review of electron spin resonance and its applications to the study of paramagnetic defects in crystalline quartz. Phys. Chem. Minerals 10, 149-165.

YIP, K.L. \& FowLER, W.B. (1975): Electronic structure of $E_{1}$ ' centers in $\mathrm{SiO}_{2}$. Phys. Rev. B B11, 2327-2338.

Zhang, Guangyu, Wasyliuk, K. \& Pan, Yuanming (2001): The characterization and quantitative analysis of clay minerals in the Athabasca Basin, Saskatchewan: application of shortwave infrared reflectance spectroscopy. Can Mineral. 39, 1347-1363.

ZINKERNAGEL, U. (1978): Cathodoluminescence of quartz and application to sandstone petrology. Contrib. Sed. 8, 1-69.

Received September 1, 2004, revised manuscript accepted April 15, 2005. 